\title{
Lung Papilloma
}

National Cancer Institute

\section{Source}

National Cancer Institute. Lung Papilloma. NCI Thesaurus. Code C8295.

A benign papillary neoplasm that arises endobronchially. It is classified as squamous cell, glandular, or mixed squamous cell and glandular papilloma. Patients usually present with signs and symptoms of bronchial obstruction. 